\title{
EX-ANTE ROBUSTNESS MEASURES FOR SINGLE TRACK TRAIN TIMETABLES
}

\author{
Malik Muneeb Abid, Muhammad Babar Khan, Xinguo Jiang
}

Preliminary communication

The goal of the paper is to propose a measurement to quantify and improve the robustness of the train timetables at the design stage. The paper presents the modeling and application of an ex-ante robustness measure for single track railways, known as the Critical Robustness Measure (CRM). Efficiency of the CRM is demonstrated by comparing the technique with the available ex-ante robustness measures, e.g., the number of trains per hour per section, the total amount of runtime margin for each individual train, sum of shortest headway reciprocals, weighted average distance, marginal runtime difference, robustness at the critical points, and margins along the longest path. Numerical experiment sare conducted on a hypothetical example and a selected single track segment of the Pakistan Railways. Computational results reveal that it is not useful to add the time margins to all activites (e.g., running times, headways) in the timetable because not all components of margins are effective for the robustness of a timetable. Furthermore, the robustness is not statically quantifiable, since it may change with time and be associated with the way of the train's interactions.

Keywords: critical points; ex-ante measures; robustness measurement; train timetable

Ex-ante mjere dugotrajnosti za vozne redove jednokolosiječne željezničke pruge

Prethodno priopećenje Cilj je ovoga rada predložiti mjerenje u svrhu kvantificiranja i poboljšanja dugotrajnosti voznih redova već kod izrade. U radu se predstavlja modeliranje i primjena ex-ante mjere dugotrajnosti za vozne jednokolosiječne željezničke pruge, poznate kao Critical Robustness Measure (CRM). Učinkovitost te mjere demonstrira se usporedbom te metode $s$ dostupnim ex-ante mjerama izdržljivosti, tj. brojem vlakova po satu po dionici, ukupnim iznosom granice vremena vožnje za svaki pojedinačni vlak, zbirom najkraćih uzajamnih vemenskih intervala između dva vlaka, ponderiranim prosjekom udaljenosti, marginalnom razlikom u vremenu vožnje, izdržljivosti u kritičnim točkama, i granicama vremena vožnje na najdužoj stazi. Numerički eksperimenti provedeni su na hipotetičkom primjeru i izabranom dijelu jednokolosiječne pruge na pakistanskim željeznicama. Rezultati proračuna pokazuju da nije korisno dodati vremenska ograničenja kod svih aktivnosti (na pr. vrijeme vožnje, vremenski razmak između dva vlaka) u voznom redu jer nisu sve komponente uključene u granicu vremena vožnje korisne za dugotrajnost nekog voznog reda. Nadalje, ta se dugotrajnost ne može statistički kvantificirati budući da se tijekom vremena može promijeniti i povezati s načinom interakcija između vlakova.

Ključne riječi: ex-ante mjere; kritične točke; mjerenje dugotrajnosti (izdržljivosti); vozni red vlaka

\section{Introduction}

Robustness is an important parameter in the train timetable design. During the last few years, transportation researchers have had great interests in finding the optimal and efficient timetable and particularly focusing on finding the robust solutions. Robustness means that the conflicting train routes are spread over the time as much as possible so that timetable is "insensitive to the small delays" $[17,18]$. According to Andersson et al. [1, 2, and $3]$, in the robust timetable trains are able to keep their original timeslots despite the small primary delays and without causing the unrecoverable delays to other trains.

Based on the time of robustness evaluation, robustness measures can be classified as: ex-ante and expost measures. Ex-ante evaluation is carried out at the design stage and related to the characteristics of timetable (e.g., headway, margins, and slack times). Comparatively, ex-post evaluation is conducted after the simulation or real-world execution and based on the traffic performance. Real time or simulated traffic performance measures rely on the behaviour of timetable when confronting disturbances, whereas measures related to timetable characteristics can be calculated at the design stage without the knowledge of disturbances. Fig. 1 illustrates the difference of these two measures.

Ex-post robustness measurement is common in both industry and research. Generally, it is presented in the form of average delay (Khan and Zhou [11], Fischetti et al. [9], Kroon et al. [14], and Vromans et al. [20]), secondary and total delay (Larsen et al. [15]), punctuality (Andersson et al. [3]), and the number of affected passengers (Dewilde et al. [8]). However, the importance of the ex-ante measures cannot be denied because the traffic performance is based on the design quality of the timetable. The scope of the paper is limited to the ex-ante measures which are useful at the design stage of a timetable.

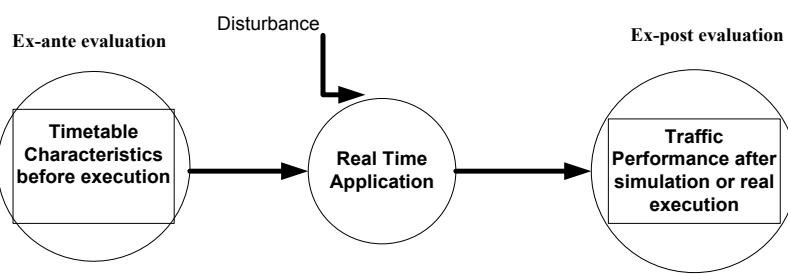

Figure 1 Difference between timetable and traffic measures

Tab. 1 summarizes the synthesis of the related work. Classification is based on the key factors and significance of the study. Salido et al. [17, 18] used traffic density (trains per hour per section) to represent the robustness in terms of capacity utilization as well as bottlenecks. Vromans et al. [20] considered the headways between trains to include the heterogeneity of traffic for the robustness evaluation and proposed the sum of shortest headway reciprocals $(S S H R)$, showing the spread of trains over time. Carey [4] and Kroon et al. [13] introduced the percentage of headways $(\mathrm{PoH})$ equal to or less than the minimum value to take into account the train interactions reluctant to the delay absorption. Total amount of runtime margins for each individual train (TAoRM) indicated the ability of a train to recover from delays [6]. The amount of margins in the timetable has significant impacts on all 
the ex-ante robustness measures. Margins can be added to the different component parts of the timetable, e.g., headway and running time. These margins help to avoid trains from arriving late despite the small delays and reduce the knock-on effects of delays. However, margins may increase the travel time and capacity consumption of the railway network [21]. Therefore, Schöbel and Kratz [19] and Cicerone et al. [5] proposed the price of robustness to calculate the effect of the increased margins, which was defined as the ratio between the cost of the robust timetable and the optimal timetable without robustness. Kroon et al. [12] and Fischetti et al. [9] proposed weighted average distance $(W A D)$ to find the distributions of runtime margins for a particular train.

Table 1 Ex-ante robustness measures for train timetable

\begin{tabular}{|c|c|c|}
\hline Publication & $\begin{array}{l}\text { Timetable parameter for ex- } \\
\text { ante evaluation }\end{array}$ & Significance \\
\hline \multicolumn{3}{|l|}{ Traffic density } \\
\hline $\begin{array}{l}\text { Salido et al. }[17, \\
18]\end{array}$ & Number of trains $(N o T)$ & $\begin{array}{l}\text { Useful to point out } \\
\text { the bottleneck in the } \\
\text { network. }\end{array}$ \\
\hline \multicolumn{3}{|l|}{ Margins } \\
\hline \multicolumn{3}{|l|}{ Headway } \\
\hline $\begin{array}{l}\text { Vromans et al. } \\
{[20]}\end{array}$ & $\begin{array}{l}\text { Sum of shortest headway } \\
\text { reciprocals }(S S H R)\end{array}$ & \multirow{2}{*}{$\begin{array}{l}\text { Identify the conflict } \\
\text { points } \\
\text { where the margin } \\
\text { values are not } \\
\text { sufficient. }\end{array}$} \\
\hline $\begin{array}{l}\text { Carey [4] and } \\
\text { Kroon et al. [13] }\end{array}$ & $\begin{array}{l}\text { Percentage of headways equal } \\
\text { to or less than the minimum } \\
\text { value }(\mathrm{PoH})\end{array}$ & \\
\hline \multicolumn{3}{|c|}{ (1) } \\
\hline $\begin{array}{l}\text { Salido et al. [17, } \\
18] \text { and De Fabris } \\
\text { et al. [6] }\end{array}$ & $\begin{array}{l}\text { Total amount of runtime } \\
\text { margin for each individual } \\
\text { train }(T A o R M)\end{array}$ & \multirow{4}{*}{$\begin{array}{l}\text { Recognize the } \\
\text { runtime margin } \\
\text { allocation } \\
\text { along the train } \\
\text { paths. }\end{array}$} \\
\hline $\begin{array}{l}\text { Kroon et al. [12] } \\
\text { and Fischetti et al. } \\
\text { [9] }\end{array}$ & $\begin{array}{l}\text { Weighted average distance } \\
(W A D)\end{array}$ & \\
\hline Vromans et al. & $\begin{array}{l}\text { Marginal runtime difference } \\
(M R D)\end{array}$ & \\
\hline Goverde $[10]$ & $\begin{array}{l}\text { Margin along the longest path } \\
(M L P)\end{array}$ & \\
\hline \multicolumn{3}{|c|}{ Headway and runtime } \\
\hline $\begin{array}{l}\text { Andersson et al. } \\
{[1,2,3]}\end{array}$ & $\begin{array}{l}\text { Robustness in critical points } \\
(R C P)\end{array}$ & $\begin{array}{l}\text { Consider the margin } \\
\text { availability at train } \\
\text { interaction } \\
\text { points. }\end{array}$ \\
\hline This Paper & $\begin{array}{l}\text { Critical robustness measure } \\
(C R M)\end{array}$ & $\begin{array}{l}\text { Consider only those } \\
\text { margins which play } \\
\text { part in robustness. }\end{array}$ \\
\hline \multicolumn{3}{|l|}{ Capacity utilization } \\
\hline Cicerone et al. [5] & Price of robustness $(P o R)$ & $\begin{array}{l}\text { Provide a } \\
\text { comparison between } \\
\text { the capacity and } \\
\text { robustness. }\end{array}$ \\
\hline
\end{tabular}

$W A D$ is a relative number between 0 and 1 , where $W A D>0.5$ shows that more margin is placed in the second half of the considered train and $W A D=0.5$ means both halves have an equal distribution of margins. Goverde [10] introduced the concept of the critical path in the train timetable and calculated the available margins along the critical path. Critical path is the sequence of activities with the longest duration and delay to any of the activity along the path increases the whole duration of the timetable. According to Andersson et al. [1, 2 and 3], robustness is related to the margins available at the critical points in the timetable. Critical points are located where trains enter and overtake the previously running train. For one way traffic, robustness at the critical points (RCP) consists of three components (Fig. 2): i) available runtime margin for operating train before the critical point; ii) available runtime margin for operating train after the critical point; and iii) headway margins between the departure times at the critical points. $R C P$ calculations have a major drawback, which do not consider the overlap of margins. The point can be elaborated in Fig. 2, for example, at station $\mathrm{C}$ runtime margin of train 3 overlaps with the headway margin of train 2 .

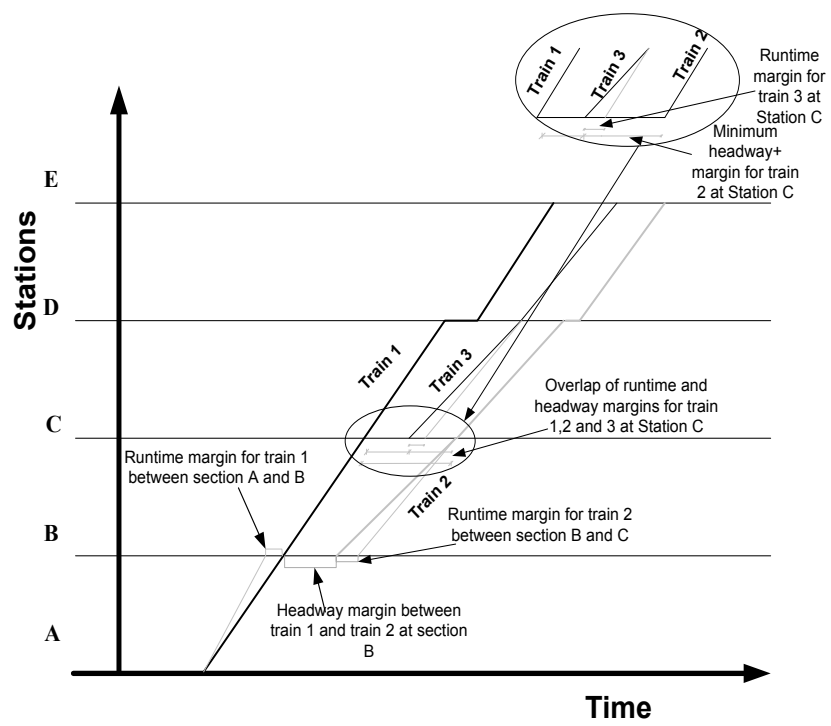

Figure 2 Robustness in critical points $[1,2,3]$

Analyzing the weakness of the timetable by identifying the delay-sensitive train slots or line sections is a common approach in the available ex-ante robustness measures [9, 11, 12, and 17]. Available measures can be used to point out the trains having inefficient margin allocation or possessing inappropriate amount of margins, however, it cannot provide any advice about the amount of margins and suitable insertion places for the margin to increase the robustness. Moreover, these measures have been developed for double track timetables without considering the overtaking and complex train conflicts for single track lines. It has been reported in [1, 2, and 3] that all the available headways and runtime margins play important part in the robustness. While in the actual practice delay absorbed after disruptions may not be equal to the sum of the available margins in the timetable. In addition, the available approaches quantify the robustness value statistically; however, the effect of disruption is random and generates different delays at different points of the same timetable.

These limitations are significant, and serve as the motivation of the study. The paper attempts to offer the following contributions to the growing body of research work on the train timetable robustness evaluation:

1) The paper presents the modeling of ex-ante robustness measures for single line train timetable. Case studies show that not all components of the margins (headways and runtimes) in the timetable are useful to absorb the disruptions. Moreover, the value of the robustness of a timetable is not constant, which changes with time.

2) Based on the useful components of margins, the paper proposes an ex-ante single track train timetable robustness measure, which not only provides the robustness evaluation but suggests the improvements. 
At the design stage planners can use the measure to assess the robustness and apply the modifications by choosing different options, e.g., changing the routes or the order of trains.

The paper is organized as follows. Section 2 presents the modeling details for the robustness measurement. Section 3 shows a simulated example and a real world case. And the last section presents the conclusions and recommendations for the future research.

\section{Methodology}

The section provides the modeling details of ex-ante robustness measures for the train timetables. Robustness measures are modified to fit the single track train timetables. Tab. 2 enlists the notations and variables used in the modeling exercise. The section includes the formulae for calculating the robustness measures, a detailed modeling for the $C R M$ for single track train timetables, and the algorithm for the proposed calculations.

Table 2 Table of notations

\begin{tabular}{|l|c|}
\hline \multicolumn{1}{|c|}{ Parameter } & Symbol \\
\hline Start time & $s_{i, j}$ \\
\hline End time & $e_{i, j}$ \\
\hline Minimum occupation time & $d_{j}^{\text {start }}$ \\
\hline Headway at the start of section & $H^{\text {end }}$ \\
\hline Headway at the end of section & $J$ \\
\hline Set of Sections, with index j for each section & $T$ \\
\hline $\begin{array}{l}\text { Set of Trains, with index i for inbound train, i' for } \\
\text { outbound train }\end{array}$ & $R m_{i, j}$ \\
\hline Runtime margin & $g_{i, \hat{i}, j}$ \\
\hline $\begin{array}{l}\text { Minimum headway between arrival times of two } \\
\text { consecutive trains at station }\end{array}$ & $h_{i, \hat{i}, j}$ \\
\hline $\begin{array}{l}\text { Minimum headway between arrival and departure } \\
\text { times of two consecutive trains at station }\end{array}$ & $e_{i, \hat{i}, j}$ \\
\hline $\begin{array}{l}\text { Minimum headway between departure of two } \\
\text { consecutive trains from a station }\end{array}$ & $P_{i, \hat{i}, j}$ \\
\hline Set of conflict points $p$ & $v_{\mathrm{b}}$ \\
\hline $\begin{array}{l}\text { Number of arrivals of two consecutive trains within } \\
\text { conflict window b }\end{array}$ & $\gamma_{\mathrm{b}}$ \\
\hline $\begin{array}{l}\text { Number of arrival and departure times of two } \\
\text { consecutive trains within conflict window b }\end{array}$ & \\
\hline $\begin{array}{l}\text { Number of departure of two consecutive trains from a } \\
\text { station within conflict window b }\end{array}$ & \\
\hline
\end{tabular}

\subsection{Ex-ante parameters}

\subsubsection{Number of trains (NoT)}

Traffic density (trains per hour per section) is expressed with the parameter. It can be used for the capacity utilization as well as identifying the bottlenecks [17]. The measure works in the same manner for both single and double track railway lines.

Number of Trains (NoT)

$\sum s_{i, j}<3600$ (for one hour)

\subsubsection{Total amount of runtime margin for each individual train (TAoRM)}

The variable shows the ability of an individual train to recover from the delays, introduced by Salido et al. [17]. It can be applicable for both single and double track lines.

$$
\begin{aligned}
& \text { TAoRM }=\sum R m_{i, j} \\
& R m_{i, j}=e_{i, j}-s_{i, j}-d_{j} .
\end{aligned}
$$

\subsubsection{Sum of shortest headway reciprocals (SSHR)}

Vromans et al. [20] proposed the parameter to consider the heterogeneity of traffic. It shows the spread of trains over time. The drawback is that it puts the same value of penalty for both arrival and departure headways, while in practice arrival headways are more crucial. In order to count for the deficiency, Vromans et al. [20] introduced a new measure named SAHR (sum of the arrival headways reciprocal).

$$
\begin{aligned}
& \text { if }\left(H_{i, i^{\prime}}^{\mathrm{start}} \leq H_{i, i^{\prime}}^{\mathrm{end}}\right) \rightarrow S S H R=\sum \frac{1}{H_{i, i^{\prime}}^{\text {start }}} \\
& \text { if }\left(H_{i, i^{\prime}}^{\mathrm{start}}>H_{i, i^{\prime}}^{\mathrm{end}}\right) \rightarrow S S H R=\sum \frac{1}{H_{i, i^{\prime}}^{\mathrm{end}}}
\end{aligned}
$$

It is modified to fit the single track train timetables. At the beginning and end of sections, track headways are measured irrespective of the interaction between trains, i.e., arrival-arrival, departure-arrival, and departuredeparture points. Thus, for the single track train timetables the measure includes both arrivals and departures headways of trains at every station.

\subsubsection{Weighted average distance (WAD)}

Kroon et al. [12] and Fischetti et al. [9] used the parameter to find the distribution of runtime margins for a particular train. It can be used for single and double track lines.

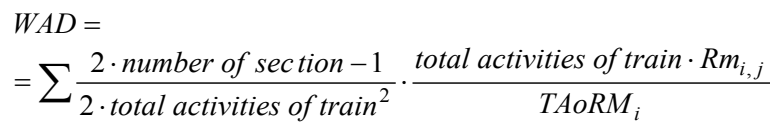

\subsubsection{Percentage of headways equal to or less than the minimum value $(\mathrm{PoH})$}

Carey [4] and Kroon et al. [14] introduced the measure to take into account the number of headways less than the minimum value.

$$
\begin{aligned}
& N H=\sum\left(H_{i, i^{\prime}}^{\text {start }} \text { or } H_{i, i^{\prime}}^{\text {end }} \leq H \mathrm{~min}\right) \\
& \text { PoH }=\frac{N H}{\text { total number of headways }} \cdot 100 \%
\end{aligned}
$$

All headways between arrival-arrival, departurearrival, and departure-departure points are considered to fit the single track train timetables. 


\subsubsection{Marginal runtime difference (MRD)}

$M R D$ parameter was introduced by Vromans et al. [20] to include the heterogeneity in the traffic, which compared the runtime differences between slow and fast running trains at the track. Andersson et al. [1] used the $M R D$ by dividing the whole track into partial stretches, which were naturally bounded by the traffic structures. It is used for both directional trains by dividing the network into partial stretches based on the traffic conditions.

\subsubsection{Robustness in critical points (RCP)}

Andersson et al. [1, 2, 3] identified the limitations of RCP that it considered all the headways and runtime margins in the robustness while in reality not all of these margins were effective and focused on the double line train traffic only. Considering the limitations of $R C P$, $C R M$ is concentrated on those margins which are useful for the robustness of single track train traffic.

\subsubsection{Margin along the longest path (MLP)}

Goverde [10] introduced the parameter. Formulation is based on the directed acyclic graph in which train passing a section or station is considered as an activity. Sequence of activities along the longest path is considered as the critical path/longest path. Margin time available to these activates is calculated as follows:

Critical path $=\max \left\{C_{k}\right\}$

Margin along the longestpath (MLP) $=\sum_{i \in T} \sum_{j \in J} R m_{i, j}\left\{\mathrm{O}_{\mathrm{k}}\right\}(8)$

\subsection{Modeling robustness calculation of single line train timetables}

$C R M$ is based on the runtime and headway margins at the conflicting points, quantifying the robustness of timetable. Conflict points considered for $C R M$ are defined as those points where a train has the interaction with other trains, i.e., overtaking, crossing, and entrance of new train at segments where a train is already running.

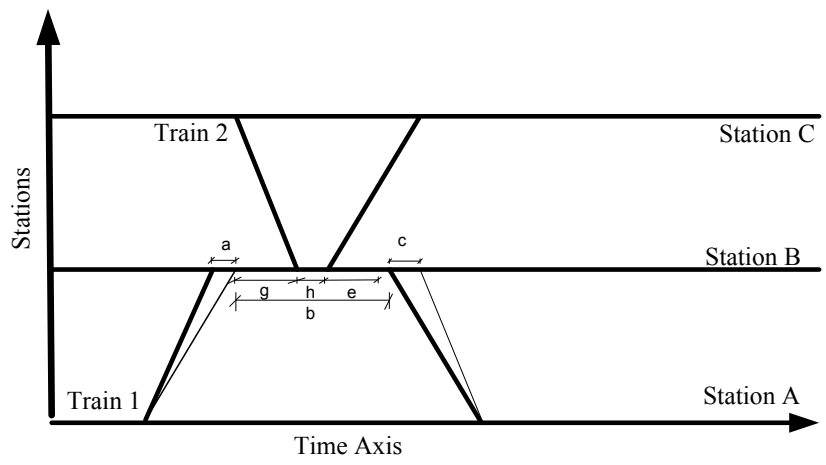

Figure 3 Calculation of RM for single track railways

Fig. 3 shows the schematic diagram to calculate the $C R M$ value for single track railways. The horizontal and vertical axes represent the time and the stations, respectively. Algorithm 1 is designed for the CRM calculations.

Where $\mathrm{a}$ is the runtime margin of train 1 before the conflict point from the previous point in the timetable where the train had a fixed departure time;

$\mathrm{b}$ is the conflict time window; and

c is the runtime margin for train 2 after the conflict point to the next point in the timetable where the train has a fixed arrival time.

Critical Robustness Measure

$$
\begin{aligned}
C R M= & a+b+c- \\
& -\left\{\left(v_{\mathrm{b}} \cdot g_{i, \hat{i}, j}\right)+\left(\gamma_{\mathrm{b}} \cdot h_{i, \hat{i}, j}\right)+\left(\varphi_{\mathrm{b}} \cdot e_{i, \hat{i}, j}\right)\right\}
\end{aligned}
$$

\section{Computational experiments}

The section presents the experiments conducted for the calculations of the ex-ante parameters for a small simulated example and the real world case of single track train timetable. Comparison of the previous and proposed approaches is performed to observe the efficiency of the proposed measure $C R M$
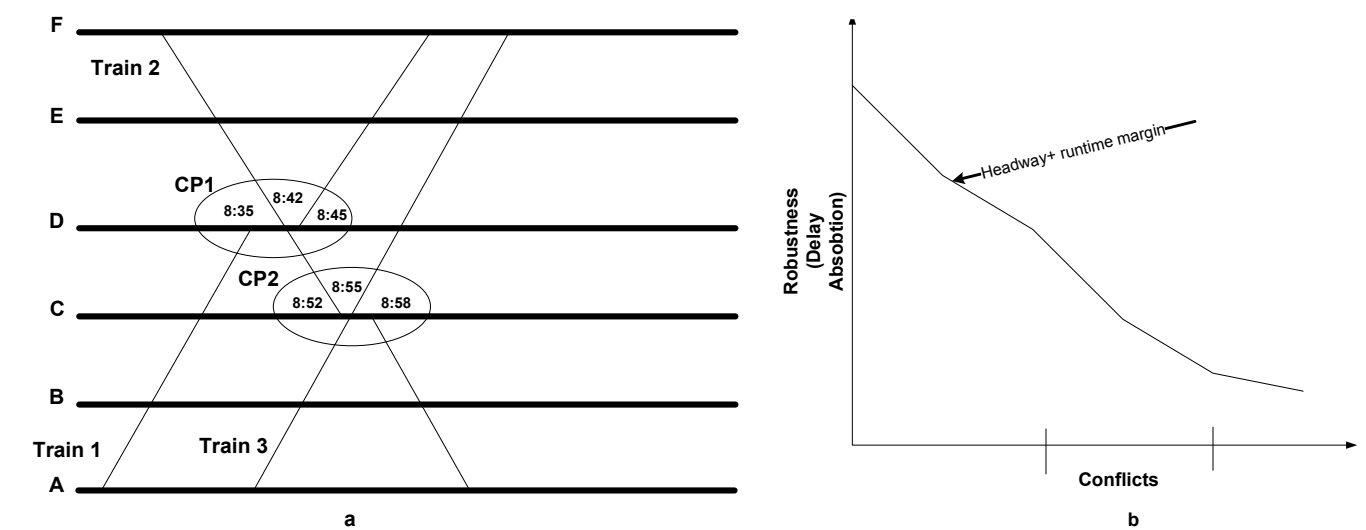

Figure 4 (a) Graphical illustration of timetable for example calculations (b) Illustration of the variations of the robustness value with respect to time.

\subsection{Example}

Fig. 4 illustrates the timetable in the graphical form and Tab. 3 shows the timetable in the tabular format.
Also shown in Tab. 3 is the runtime margins explicitly without considering the dwell time margins.

In Fig. $4 \mathrm{CP} 1$ and $\mathrm{CP} 2$ are both conflicts between trains running in the opposite directions. CP1 is the conflict between train 1 and train 2 , where train 1 waits at 
station $\mathrm{D}$ and the priority is given to train 2 . Both the arrival and departure headways are 3 minutes for the conflict. At $\mathrm{CP} 2$, the priority is given to train 3 without the headway margin.

Conflicts are the interaction points of trains and these interaction points allow for the absorption/propagation of delays. Hence, the robustness is the disruption absorption capability of these conflict points such that trains may be able to retain their positions after the occurrence of the disruptions. At $\mathrm{CP} 1$, train 2 has to pass between the conflict window $(8: 35-8: 45)$. It is obvious that the runtime margins provided to train 2 for sections DE and EF will help to cater the processing disruptions at DE and EF.
Considering the runtime margins of train 1 with respect to $\mathrm{CP} 1$, it has the significant impacts on the robustness of timetable, because it is train 1 that influences the conflict window before and after the CP1. Thus, margins of train 1 can expand the $\mathrm{CP} 1$ window to enhance the delay absorption capacity. Likewise, the runtime margins of train 2 before and after CP2 can significantly impact the robustness of the timetable, whereas the runtime margin of train 3 only helps train 3 to reach $\mathrm{CP} 2$ at time but cannot play any part at the point of interaction CP2. Moreover, the margin of train 3 is already considered in the margin of the conflict window.

Table 3 Timetable for example calculations

\begin{tabular}{|c|c|c|c|c|c|c|c|c|}
\hline \multirow{2}{*}{ Station } & \multicolumn{5}{|c|}{ Timetable 1} & \multicolumn{3}{|c|}{ Runtime margin (s) } \\
\hline & Time & Train 1 & Train 3 & Time & Train 2 & Train 1 & Train 2 & Train 3 \\
\hline \multirow{2}{*}{ A } & Arrival & & & Departure & & & & \\
\hline & Departure & $8: 05$ & $8: 35$ & Arrival & $9: 18$ & \multirow{2}{*}{30} & \multirow{2}{*}{20} & \multirow{2}{*}{30} \\
\hline \multirow{2}{*}{ B } & Arrival & $8: 15$ & $8: 45$ & Departure & 9:08 & & & \\
\hline & Departure & $8: 15$ & $8: 45$ & Arrival & 9:08 & \multirow{2}{*}{30} & \multirow{2}{*}{30} & \multirow{2}{*}{30} \\
\hline \multirow{2}{*}{$\mathrm{C}$} & Arrival & $8: 25$ & $8: 55$ & Departure & $8: 58$ & & & \\
\hline & Departure & $8: 25$ & $8: 55$ & Arrival & $8: 52$ & \multirow{2}{*}{30} & \multirow{2}{*}{30} & \multirow{2}{*}{30} \\
\hline \multirow{2}{*}{ D } & Arrival & $8: 35$ & 9:05 & Departure & $8: 42$ & & & \\
\hline & Departure & $8: 45$ & 9:05 & Arrival & $8: 42$ & \multirow{2}{*}{20} & \multirow{2}{*}{30} & \multirow{2}{*}{20} \\
\hline \multirow{2}{*}{$\mathrm{E}$} & Arrival & 9:00 & $9: 20$ & Departure & $8: 27$ & & & \\
\hline & Departure & 9:00 & $9: 20$ & Arrival & $8: 27$ & \multirow{2}{*}{10} & \multirow{2}{*}{30} & \multirow{2}{*}{10} \\
\hline \multirow{2}{*}{$\mathrm{F}$} & Arrival & $9: 10$ & $9: 30$ & Departure & $8: 17$ & & & \\
\hline & Departure & & & Arrival & & & & \\
\hline
\end{tabular}

\begin{tabular}{|c|c|c|c|c|c|c|c|}
\hline Section & NoT & SSHR & Train & TAoRM & $W A D$ & Conflict points & $C R M$ \\
\hline A-B & 3 & 0.001280193 & 1 & 120 & 0.468 & 1 & 360 \\
\hline $\mathrm{B}-\mathrm{C}$ & 3 & 0.006111111 & 2 & 140 & 0.473 & 2 & 80 \\
\hline C-D & 3 & 0.007222222 & 3 & 120 & 0.468 & $M L P$ & 420 \\
\hline D-E & 3 & 0.007936568 & & & & $\mathrm{PoH}$ & $21.4 \%$ \\
\hline E-F & 3 & 0.001338384 & & & & & \\
\hline
\end{tabular}

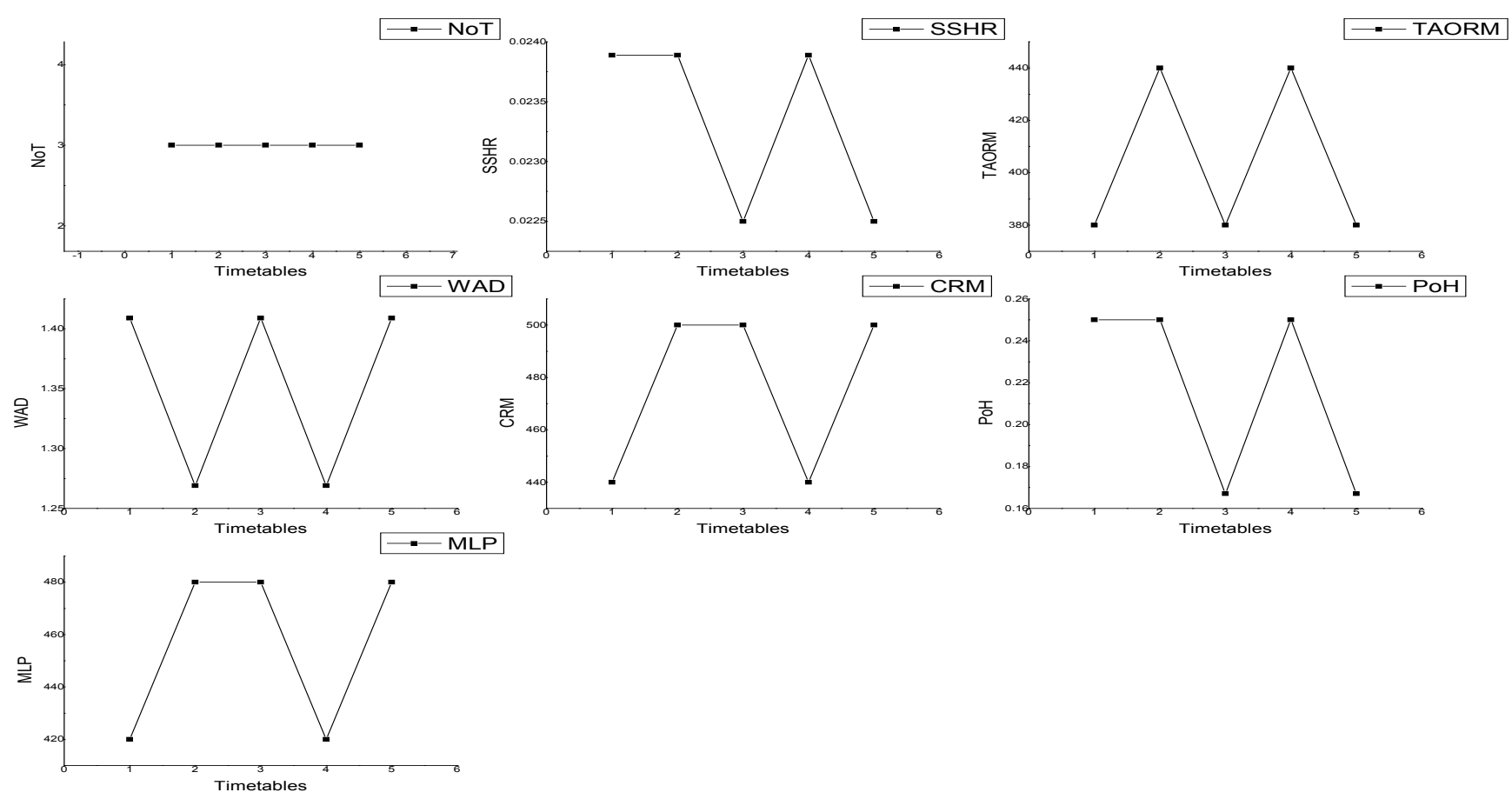

Figure 5 Comparison of different ex-ante approaches 
The margins before the CP1 can help to bear the disruptions prior to the point and cannot help to absorb the disruption occurring at or after CP2. Fig. 4 (b) can also explain the phenomenon clearly that robustness of a timetable is the delay absorption capability of whole timetable. It is not constant, which changes with time and depends on the interaction points of trains. At the start all the margins are available to absorb the disruptions and at the end all margins are utilized. Availability of the margins in between the start and end point varies with time.

Tab. 4 summarizes the calculations of robustness parameters. The measures are divided into the railway sections, operating trains and conflict points. $\mathrm{PoH}$ in the example is $21.4 \%$. Among the total 14 headways, 3 headway values (i.e., headway between train 2 arrival and train 1 departure; train 2 arrival and train 3 departure; and train 3 arrival and train 2 departure) equal to the minimum value (3 minutes).

Table 5 Schematic arrangement for modification of timetable

\begin{tabular}{|c|c|c|c|c|c|c|c|c|c|c|c|c|c|}
\hline \multirow{2}{*}{ Station } & & \multicolumn{3}{|c|}{ Timetable 2} & \multicolumn{3}{|c|}{ Timetable 3} & \multicolumn{3}{|c|}{ Timetable 4} & \multicolumn{3}{|c|}{ Timetable 5} \\
\hline & & Train 1 & Train 3 & Train 2 & Train 1 & Train 3 & Train 2 & Train 1 & Train 3 & Train 2 & Train 1 & Train 3 & Train 2 \\
\hline \multirow{2}{*}{ A } & Arrival & & & & & & & & & & & & \\
\hline & Departure & $8: 04$ & $8: 35$ & $9: 18$ & $8: 05$ & $8: 35$ & $9: 18$ & $8: 05$ & $8: 34$ & $9: 18$ & $8: 05$ & $8: 35$ & $9: 18$ \\
\hline \multirow{2}{*}{ B } & Arrival & $8: 15$ & $8: 45$ & $9: 08$ & $8: 15$ & $8: 45$ & $9: 08$ & $8: 15$ & $8: 45$ & $9: 08$ & $8: 15$ & $8: 45$ & $9: 08$ \\
\hline & Departure & $8: 15$ & $8: 45$ & 9:08 & $8: 15$ & $8: 45$ & 9:08 & $8: 15$ & $8: 45$ & 9:08 & $8: 15$ & $8: 45$ & 9:08 \\
\hline \multirow{2}{*}{$\mathrm{C}$} & Arrival & $8: 25$ & $8: 55$ & $8: 58$ & $8: 25$ & $8: 55$ & $8: 58$ & $8: 25$ & $8: 55$ & $8: 58$ & $8: 25$ & $8: 55$ & $8: 59$ \\
\hline & Departure & $8: 25$ & $8: 55$ & $8: 52$ & $8: 25$ & $8: 55$ & $8: 52$ & $8: 25$ & $8: 55$ & $8: 52$ & $8: 25$ & $8: 55$ & $8: 52$ \\
\hline \multirow{2}{*}{$\mathrm{D}$} & Arrival & $8: 35$ & $9: 05$ & $8: 42$ & $8: 35$ & 9:05 & $8: 42$ & $8: 35$ & 9:05 & $8: 42$ & $8: 35$ & $9: 05$ & $8: 42$ \\
\hline & Departure & $8: 45$ & $9: 05$ & $8: 42$ & $8: 46$ & $9: 05$ & $8: 42$ & $8: 45$ & $9: 05$ & $8: 42$ & $8: 45$ & $9: 05$ & $8: 42$ \\
\hline \multirow{2}{*}{$\mathrm{E}$} & Arrival & $9: 00$ & $9: 20$ & $8: 27$ & $9: 00$ & $9: 20$ & $8: 27$ & $9: 00$ & $9: 20$ & $8: 27$ & $9: 00$ & $9: 20$ & $8: 27$ \\
\hline & Departure & $9: 00$ & $9: 20$ & $8: 27$ & 9:00 & $9: 20$ & $8: 27$ & $9: 00$ & $9: 20$ & $8: 27$ & $9: 00$ & $9: 20$ & $8: 27$ \\
\hline \multirow{2}{*}{$\mathrm{F}$} & Arrival & $9: 10$ & $9: 30$ & $8: 17$ & $9: 10$ & $9: 30$ & $8: 17$ & $9: 10$ & $9: 30$ & $8: 17$ & $9: 10$ & $9: 30$ & $8: 17$ \\
\hline & Departure & & & & & & & & & & & & \\
\hline
\end{tabular}

Algorithm 1 Algorithm to calculate CRM value

Inputs: Railway Network, Set of trains, Arrival, Departure and Dwell times of trains, Conflict points Output: Robustness Measure (RM)

for all Conflict points $\left(p \in P_{i, \hat{i}, j}\right)$

for all pair of conflicting trains $(i, \hat{i})$

If $\mathrm{p}$ is the first conflict in trains path Calculate RM

Else Find the adjacent Conflict points of trains $(i, \hat{i})$ If adjacent conflict point is at the consecutive section

Find the margin of this section already utilized in previous Conflict

If already used then

Update RM= RM- margin of this section

\section{End}

\section{End}

End

End for

End for

It is relatively easy to calculate the NoT in the example because all the tracks have the same number of trains during the time interval 8:00-9:00. SSHR value is higher for two segments: C-D and D-E. It is due to the fact that the headway between C-D and D-E is smaller compared to other sections. It is also observed that the sections bearing the conflicts have the high value of SSHR in the given example.

$T A o R M$ is the ability of train to remain on time in spite of delays at the start. Train 2 has more margins in contrast to other two trains. WAD values less than 0.5 suggest that trains have more margins at the first half of journey. Overall, the $W A D$ value is close to 0.5 , indicating that margins are approximately equally distributed along the route.

There are two conflict points in the example: $\mathrm{CP} 1$ and CP2. Headway margin for CP1 is 240 seconds and CP2 does not have the headway margin. Train 1 has 90 and 30 seconds of runtime margins before and after the critical point, respectively. At CP2 train 2 has 30 and 50 seconds runtime margins contributing to the $C R M$. The longest sequence of actvities in the timetable is known as critical path and margins along the longest path $(M L P)$ for this example is 420 , which is close to the $C R M$ value. It can be inferred that $C R M$ contains those activities which are crtical for the timetable. Next section will discuss this observation in details.

\subsection{Sensitivity analysis}

Basically, CRM is composed of two parts: headway and runtime margins. In order to increase the robustness at the conflict points, more margins can be supplied to achieve the higher robustness. Timetable 1 is modified to show the impact of changing headway and runtime margins on the robustness. Tab. 5 shows the modifications of headways and runtimes margins from Timetable 2 to Timetable 5. The first modification is the addition of one minute runtime margin to train 1 by departing the train early from station A. The second modification is to increase the headway margin between train 1 and train 2 at $\mathrm{CP} 1$. The third modification is to increase the runtime margins for train 3 by the addition of one minute runtime margin at the origin. The fourth modification is to increase the headway margin by departing train 2 one minute late after CP2.

All the modified timetables show the $C R M$ values ranging from 440 to 500 seconds. Fig. 5 shows the impacts on other measures as well. Comparatively, Fig. 5 indicates no impact on the NoT for all the modifications, 
but the SSHR is decreased in the cases of Timetables 3 and 5. It suggests that each modification increases the headways between trains. For two modifications (Timetables 2 and 4), increasing the runtime margins is clearly depicted by the increased TAoRM. For other two modifications, TAoRM is unchanged and $P O H$ is decreased for Timetables 3 and 5. WAD is decreased for two modifications (Timetables 2 and 4), because the runtime margins are inserted at the start of journey.

It appears that all the modifications do not affect the $C R M$ values in the same manner. For example, with the runtime margins added to trains' path in Timetables 2 and 4 , for Timetable 2 increasing the runtime margin for train 1 increases the $C R M$ value but in Timetable 4 the same increased runtime margin for train 3 does not impact the $C R M$ value. As far as Timetable 3 and 5 are concerned, the increasing headway margins increases the $C R M$ value.

It is found that there is no impact on the $C R M$ value for Timetable 4. It suggests that train 3 is not influential in terms of modifying the runtime margins in Timetable 4. Reason for the phenomenon is that train 3 has a conflict with train 2, when it passes through the critical time window and its margins are already counted in the critical time window. Fig. 5 depicts that $M L P$ and $C R M$ have the same pattern for each modification. It fortifies the fact that $C R M$ focuses on the activities delay which can impact the whole timetable.

$C R M$ differs from other parameters in a way that it can illustrate the amount of margins and point out the influential margin as well. The objective of the work is to identify a measure which not only evaluates but suggests the robustness improvements to the timetable.

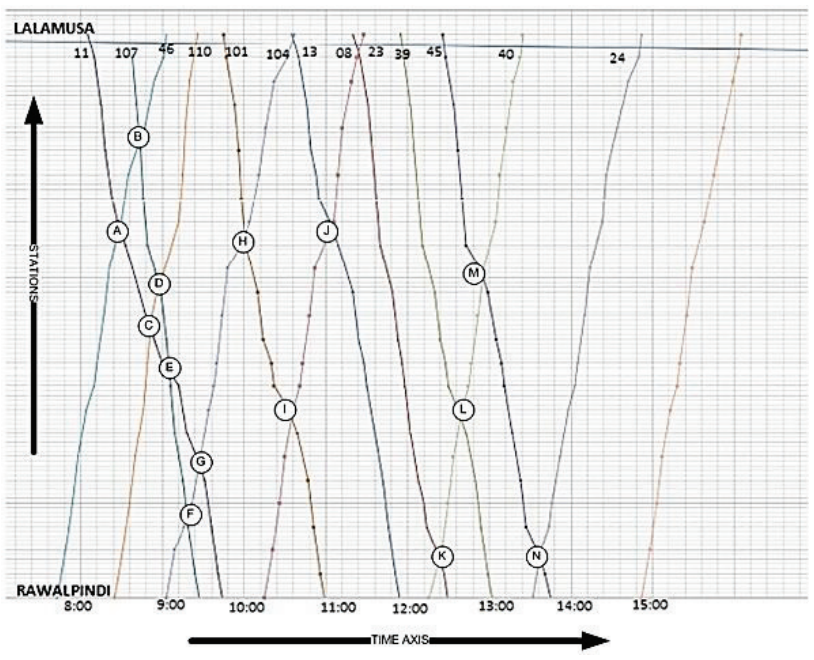

Figure 6 Actual train schedule of track segment from Rawalpindi to Lalamusa

\subsection{Real world example}

The stated robustness measures are implemented in the real world case of the Pakistan Railways provided by Rizvi [16]. The track chosen to apply the model is from Rawalpindi to Lalamusa. The selected track is mainly single line with the length of $156 \mathrm{~km}$. On the busiest week day, about 30 trains travel over the track. There are four different types of trains scheduled over the track, namely: Mail and Express, Intercity, Passenger, and Mixed trains. To ensure the safety, minimum 3-minute headway is maintained between the departure time of two trains and 2-minute interval is set between arrival times of two trains at a station. Fig. 7 displays the actual train schedule of track segments from Rawalpindi to Lalamusa.

In the work we only consider the time frame from 7:00 am to $16: 00 \mathrm{pm}$. From A to N, Fig. 6 marks 14 conflict points. In order to calculate the $M R D$, the whole network is divided into several segments. We formulate the partial stretches based on the speed restrictions provided by the Pakistan Railways, which are:

- Lalamusa to Kharian

- Kharian to Jhelum

- Jhelum to Ratial

- Ratial to Missakaswal

- Missakaswal to Rawalpindi.

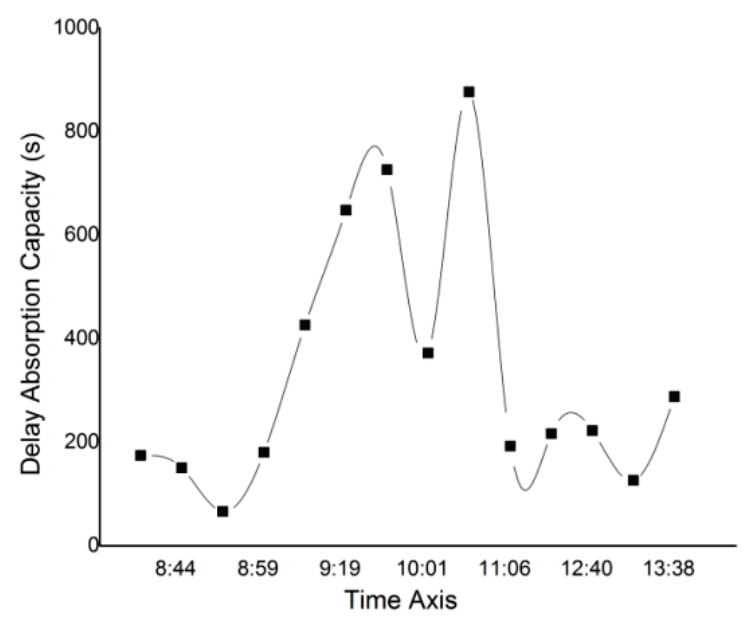

Figure 7 Timetable robustness variations with respect to the time

\subsubsection{Explanation of the results}

The overall measure of timetable $\mathrm{PoH}$ is $7.5 \%$, which means that $7.5 \%$ of headways are less than or equal to the minimum value of headway. $\mathrm{PoH}$ provides a rough estimate of headways which do not have margins. Acceptable value of $\mathrm{PoH}$ is not defined in literature [1, 14], however, it indicates that there are some headways which cannot absrob the disruptions and prone to delays.

Tab. 6 shows the values of TAoRM and WAD of inbound and outbound trains traveling on the track segment. It is important to note that the amount of run time margin for trains is approximately the same; however, it only depicts a small part of the whole timetable. Most trains start their journey outside the considered time/space zone. Therefore, by considering TAoRM and WAD only, it is hard to state that the timetable is robust. Both TAoRM and WAD are strongly related to the amount and place of disturbance occurrence. Tab. 7 shows the amount of margins allocated to the critical path in the form of $M L P$ value, which is about $25 \%$ of total amount of runtime margins. At the design stage disturbances are uncertain, however, the probability of the total delay of the timetable decreases with the increasing margins on the critical path.

Tab. 7 also shows the utilization of the network with the parameter NoT from 8 to 9 am. The result shows that the section from Lalamusa to Jhelum is highly utilized compared to other sections. The same sort of mechanism is depicted by the parameter SSHR. 
Tab. 7 shows the $M R D$ values with the difference of total amount of margin time (within brackets) among the trains having the maximum and minimum margins for a partial stretch. Itis important to note that there is a balance between the running time margin allocation of the inbound and outbound trains. Larger values of $M R D$ for inbound and outbound trains at the partial stretches are due to two reasons: i) the length of a stretch and ii) conflicts of train remaining along the stretch.

$C R M$ values for all conflict points show that there is some margin available for dispatchers to handle the disturbances. $C R M$ values ranging from 66 at point $\mathrm{C}$ to 876 at point I, provide the detailed delay absorption capacity of these conflict points. If a disturbance occurring at or before a particular conflict point is less than the amount of $C R M$, it can be absorbed by the timetable. Delay propagation will be observed, if the amount of delay is greater than the absorption capacity of the conflict.

Fig. 7 is the graphical representation of the delay absorption capacity. It shows that the robustness is not a static quantity at the starting point (one point). Rather, it is the dynamic property of timetable and changes with the time values. Fig. 7 also provides the insights in the robustness values at different time intervals of timetables. In other words, $C R M$ identifies the time slots having the low margins and needed improvements. Moreover, based on the historic data of disturbances, time margins of the particular time interval can be increased with respect to the most occurring disturbance.

PoH, SSHR, WAD, MRD, and TAoRM measure the robustness based on the factors involved in the train interactions, however, they do not consider the train interactions. MLP points out the margins of the longest sequence of activities in the timetable. It is remarkable that the $C R M$ values are always greater than $M L P$, which depicts that $C R M$ is more conservative in terms of containing margins of critical path as well as other influential activites in the timetable. $R C P$ is the first approach of considering the interactions among the trains but it has limitations: i) it adds up all the runtime and headway margins, however, all the margins are not useful in the robustness; and ii) we cannot quantify the value of robustness at the single point because the value of the robustness changes with time.

Table 6 The values of TAoRM, WAD and $R M$ for Pakistan railways schedule

\begin{tabular}{|c|c|c|c|c|}
\hline Train & TAoRM & WAD & CONFLICT POINTS & $C R M(\mathrm{~s})$ \\
\hline \multicolumn{3}{|c|}{ LLM-RWP (Inbound) } & $\mathrm{A}$ & 174 \\
\hline 11 & 1032 & 0.53939 & B & 150 \\
\hline 107 & 852 & 0.47816 & $\mathrm{C}$ & 66 \\
\hline 101 & 960 & 0.52049 & $\mathrm{D}$ & 180 \\
\hline 13 & 1026 & 0.55915 & $\mathrm{E}$ & 426 \\
\hline 23 & 972 & 0.56758 & $\mathrm{~F}$ & 648 \\
\hline 39 & 1020 & 0.57583 & $\mathrm{G}$ & 726 \\
\hline 45 & 954 & 0.52551 & $\mathrm{H}$ & 372 \\
\hline \multicolumn{3}{|c|}{ RWP-LLM (Outbound) } & I & 876 \\
\hline 46 & 948 & 0.47674 & $\mathrm{~J}$ & 192 \\
\hline 110 & 852 & 0.45597 & $\mathrm{~K}$ & 216 \\
\hline 104 & 984 & 0.49297 & $\mathrm{~L}$ & 222 \\
\hline 8 & 840 & 0.45033 & $\mathrm{M}$ & 126 \\
\hline 40 & 936 & 0.48846 & $\mathrm{~N}$ & 288 \\
\hline 24 & 996 & 0.50017 & Total & 4662 \\
\hline
\end{tabular}

Table 7 The values of NoT, SSHR, MLP and MRD for Pakistan railways schedule

\begin{tabular}{|c|c|c|c|c|c|}
\hline Section & $\begin{array}{c}N o T \\
(8-9 \mathrm{am})\end{array}$ & SSHR & Section & $\begin{array}{c}N o T \\
(8-9 \text { am) }\end{array}$ & SSHR \\
\hline Lala Musa Jn - Lala Musa Goods & 3 & 0.0000429553 & Domili - Bakrala & 1 & 0.0000455373 \\
\hline Lala Musa Goods - Chak Pirana & 3 & 0.0000430663 & Bakrala - Tarki & 1 & 0.0000446828 \\
\hline Chak Pirana - Kharian Cantt & 3 & 0.0000459137 & Tarki - Sohawa & 1 & 0.0000432900 \\
\hline Kharian Cantt - Kharian & 3 & 0.0000459137 & Sohawa - Missakaswal & 1 & 0.0000405515 \\
\hline Kharian - Choa Kariala & 3 & 0.0000461681 & Missakaswal - Gujar Khan & 1 & 0.0000377929 \\
\hline Choa Kariala - Serai Alamgeer & 3 & 0.0000468165 & Gujar Khan - Ghungila & 1 & 0.0000377929 \\
\hline Serai Alamgeer - Jhelum & 3 & 0.0000474834 & Ghungila - Mardan Jn & 1 & 0.0000366300 \\
\hline Jhelum - Kala Gujran & 2 & 0.0000439754 & Mardan Jn - Kaliamawan & 1 & 0.0000349406 \\
\hline Kala Gujran - Kaluwal & 2 & 0.0000470810 & Kaliamawan - Mankiala & 1 & 0.0000347947 \\
\hline Kaluwal - Dina & 1 & 0.0000487329 & Mankiala - Sihala & 1 & 0.0000349406 \\
\hline Dina - Ratial & 1 & 0.0000483092 & Sihala - Chaklala & 1 & 0.0000372024 \\
\hline Ratial - Domili & 1 & 0.0000473485 & Chaklala - Rawalpindi & 1 & 0.0000312110 \\
\hline \multirow{2}{*}{\multicolumn{3}{|c|}{ Partial stretch }} & \multicolumn{3}{|c|}{$M R D($ TAoRM $)$} \\
\hline & & & nbound (s) & \multicolumn{2}{|c|}{ Outbound (s) } \\
\hline Lalamusa to Kharian & & & $1380(48)$ & \multicolumn{2}{|c|}{$1140(78)$} \\
\hline Kharian to Jhelum & & & $1320(30)$ & \multicolumn{2}{|c|}{$360(42)$} \\
\hline Jhelum to Ratial & & & $540(60)$ & \multicolumn{2}{|c|}{$780(30)$} \\
\hline Ratial to Missakaswal & & & $1140(78)$ & $600(84)$ & \\
\hline Missakaswal to Rwp & & & $320(120)$ & $1380(66$ & \\
\hline & & & $M L P$ & $3126(\mathrm{~s})$ & \\
\hline
\end{tabular}




\section{Conclusions and future research}

The paper proposes a robustness measure $C R M$ to find the robustness of single track train timetables. The aim of the work is to obtain an effective robustness measure at the design stage, which can evaluate and suggest timetable modifications for the robustness improvement.

The paper discusses several techniques used to measure the train timetable robustness. Particularly, the study is focused on the ex-ante measures. Most of the previous measures are proposed for double track railways. In order to tackle the issue, the paper extends the previous measures to fit the single track railways. Comparison of approaches shows that the measures used earlier have a number of shortcomings: i) they can only identify the sections/trains with high or low values of margins and ii) they do not suggest any timetable modification to increase the robustness. CRM is found to be effective in the sense that it also provides suggestions for the improvement.

The essence of the proposed approach is that it provides insights to the margins which are functional for the robustness and reveals the dynamic nature of the robustness of a train timetable. The future research includes: i) the application of $C R M$ in the optimization model to enhance the robustness subject to the constraints of the capacity utilization; ii) the relationship between the robustness and capacity utilization; and iii) the impact of margins along the critical path on the CRM and robustness improvements.

\section{Acknowledgements}

The research was supported by the National Science Foundation of China (NSFC-71271176), the youth science and technology foundation of Sichuan Province (2014JQ0014), and the China Scholarship Council. The authors thank two anonymous reviewers for their insightful comments.

\section{References}

[1] Andersson, E. V.; Peterson, A.; Krasemann, J. T. Quantifying railway timetable robustness in critical points. // Journal of Rail Transport Planning \& Management. 3, (2013), pp. 95-110. https://doi.org/10.1016/j.jtpm.2013.12.002

[2] Andersson, E. V.; Peterson, A.; Krasemann, J. T. Improved Railway Timetable Robustness for Reduced Traffic Delays - a MILP approach. // In 6th International Conference on Railway Operations Modelling and Analysis - Rail Tokyo, 2015.

[3] Andersson, E. V.; Peterson, A.; Krasemann, J. T. Reduced railway traffic delays using a MILP approach to increase Robustness in Critical Points. // Journal of Rail Transport Planning \& Management. 5, (2015), pp. 110-127. https://doi.org/10.1016/j.jtpm.2015.09.004

[4] Carey, M. Ex ante heuristic measures of schedule reliability. // Transp. Res. Part B. 33, (1999), pp. 473-494. https://doi.org/10.1016/S0191-2615(99)00002-8

[5] Cicerone, S.; D'Angelo, G.; Di Stefano, G.; Frigioni, D.; Navarra, A. Recoverable robust timetabling for single delay: Complexity and polynomial algorithms for special cases. // J. Comb. Optim. 18, (2009), pp. 229-257. https://doi.org/10.1007/s10878-009-9247-4
[6] DeFabris, S.; Longo, G.; Medeossi, G.; Pesenti, R. Automatic generation of railway timetables based on a mesoscopic infrastructure model. // Journal of Rail Transport Planning \& Management. 4, (2014), pp. 2-13. https://doi.org/10.1016/j.jtpm.2014.04.001

[7] Dewilde, T.; Sels, P.; Cattrysse, D.; Vansteenwegen, P. Defining robustness of a railway timetable. // In: Proceedings of Rail Rome 2011. University of Rome La Sapienza and IAROR.

[8] Dewilde, T.; Sels, P.; Cattrysse, D.; Vansteenwegen, P. Improving the robustness in railway station areas. // European Journal of Operational Research. 235, (2014), pp. 276-286. https://doi.org/10.1016/j.ejor.2013.10.062

[9] Fischetti, M.; Salvagnin, D.; Zanette, A. Fast approaches to improve the robustness of a railway timetable. // Transp. Sci. 43, (2009), pp. 321-335. https://doi.org/10.1287/trsc.1090.0264

[10] Goverde, R. M. P. Railway timetable stability analysis using max-plus system theory. // Transportation Research Part B: Methodological. 41, (2007), pp. 179-201. https://doi.org/10.1016/j.trb.2006.02.003

[11] Khan, M. B.; Zhou, X. Stochastic optimization model and solution algorithm for robust double-track train-timetabling problem. // IEEE Trans. Intell. Transp. Syst. 11, (2010), pp. 81-89. https://doi.org/10.1109/TITS.2009.2030588

[12] Kroon, L.; Dekker, R.; Vromans, M. Cyclic railway timetabling: A stochastic optimization approach. // Railway Optimization LNCS 4359, (2007), pp. 41-66. https://doi.org/10.1007/978-3-540-74247-0_2

[13] Kroon, L.; Huisman, D.; Maróti, G. Optimisation models for railway timetabling. // In: Hansen, I., Pachl, J. (Eds.), Railway timetable \& traffic. 2008: Eurailpress, Hamburg.

[14] Kroon, L.; Maroti, G.; Helmrich, M.; Vromans, M.; Dekker, R. Stochastic improvement of cyclic railway timetables. // Transp. Res. Part B. 42, (2008), pp. 553-570. https://doi.org/10.1016/j.trb.2007.11.002

[15] Larsen, R.; Pranzo, M.; D'Ariano, A.; Corman, F.; Pacciarelli, D. Susceptibility of optimal train schedules to stochastic disturbances of process times. // Flexible Serv. Manuf. J. 26, 4(2013), pp. 1-24.

[16] Rizvi, H. I. Pakistan Railways Time Table, for Passenger Trains (Staff Copy). Pakistan Railways, 2010.

[17] Salido, M. A.; Barber, F.; Ingolotti, L. Robustness in railway transportation scheduling. // In: 7th World Congress on Intelligent Control and Automation. Chongqing, China, 2008, pp. 2880-2885. https://doi.org/10.1109/WCICA.2008.4594481

[18] Salido, M. A.; Barber, F.; Ingolotti, L. Robustness for a single railway line: Analytical and simulation methods. // Expert Systems with Applications. 39, (2012), pp. 1330513327. https://doi.org/10.1016/j.eswa.2012.05.071

[19] Schöbel, A.; Kratz, A. A bicriteria approach for robust timetabling. // In: Ahuja et al. (eds.), Robust and online large-scale optimization, LNCS, vol. 5868, 2009, pp. 119 144. https://doi.org/10.1007/978-3-642-05465-5_5

[20] Vromans, M.; Dekker, R.; Kroon, L. Reliability and heterogeneity of railway services. // Eur. J. Oper. Res. 172, (2006), pp. 647-665. https://doi.org/10.1016/j.ejor.2004.10.010

[21] D'Ariano, A.; Pacciarelli, D.; Pranzo, M. Assessment of flexible timetables in realtime traffic management of a railway bottleneck. // Transportation Research Part C. 16, (2008), pp. 232-245. https://doi.org/10.1016/j.trc.2007.07.006 


\section{Authors' addresses}

Malik Muneeb Abid, Ph.D Scholar

School of Transportation and Logistics,

Southwest Jiaotong University, Chengdu 610031, China.

0086-18244221541

E-mail: malik.muneeb.abid@hotmail.com

Muhammad Babar Khan, PhD, Assistant Professor

Department of Civil Engineering, College of Engineering,

Al Imam Mohammad Ibn Saud Islamic University

Riyadh 11432, Kingdom of Saudi Arabia

Office: +966112586376

E-mail:makhan@imamu.edu.sa

Xinguo "Joe" Jiang, PhD, PE PTOE, Professor, Vice Dean

(Corresponding Author)

School of Transportation and Logistics,

Southwest Jiaotong University

111 Erhuan Road, Beiyiduan, Chengdu, China

Tel: (86) 28-87600248

E-mail: xjiang@swjtu.edu.cn 